\title{
PVC/PMMA KEVERÉKEK REOLÓGIAI VISELKEDÉSÉNEK ÖSSZEHASONLÍTÁSA
}

\author{
Román Krisztina - Zsoldos Gabriella
}

\begin{abstract}
Absztrakt: Különböző PVC keverékek ömledék folyási viselkedését vizsgáltuk különbözö feldolgozási hömérsékleteken széles nyírási sebesség tartományon belül. Ezen keverékeknél, az alacsonyabb hőmérsékleten előállított polimereknél nagyobb viszkozitás figyelhető meg. A tanulmány célja a PVC/PMMA kompozitból készült keverék és natúr kemény PVC habkeverék reológiai viselkedésének összehasonlítása. A PVC ömledékben elöforduló változások várhatóan függnek az egyszerü áramlási és hỏmérsékleti igénybevételektől. Így a vizsgálat során a keverék viszkozitás értékeinek változásait figyelhetjük meg különböző hömérsékleti tartományokban. A hömérséklet emelésével a viszkozitás görbék változásával a feldolgozhatóság és a feldolgozási hömérséklet, a szerkezet módosulásaira lehet következtetni. A vizsgálati eredményekből következtetni lehet a hab feldolgozási paramétereire, továbbá a PMMA és PVC összeférhetőségére.
\end{abstract}

\begin{abstract}
The effect of processing temperature on the melt flow PVC blends has been studied with a wide shear rate range. For those blends were prepared at lower temperatures higher melt viscosity could be observed. In this paper, comparison the rheological behaviour of neat PVC and PVC/PMMA blends. In the PVC melt changes depends on the simple flow and temperature loads. We were observed the rheological values changes at different production temperature ranges. The result of the measurements can be inferred from the processing and structural modifications. By temperature increasing the processing type and the temperature can be determined. Based on results of the tests, it can be concluded that the foam parameters, as well as compatibility between PVC and PMMA.
\end{abstract}

Kulcsszavak: PVC/PMMA keverék, összeférhetőség, viszkozitás görbe, ömledék reológia

Keywords: PVC/PMMA blend, compatibility, viscosity curve, melt rheology

\section{Bevezetés}

Néhány évtizede már, hogy a polimer habokat széleskörben alkalmazzák csomagoló, szigetelö anyagokként. Kis súlyuk, erö/szilárdság arányuk és kiváló szigetelö tulajdonságaik miatt egyre gyakoribb a felhasználásuk (Ray, 2013). A mikrocelluláris PVC habokat már több sürüségben is megtalálhatjuk a kereskedelemben, amelyeket leggyakrabban az építőipar, kábelipar hasznosít (Kumar et al., 1998). Nagyon fontos manapság a keverhető polimer vagy kopolimer rendszerek kialakítása, mivel új típusú anyagok fejlesztésére a mai fejlődő technikáknak nagy szüksége van (Panayiotou, 2013).

A PMMA [poli(metil-metakrilát)] mehanikai és optikai tulajdonságai miatt is gyakran alkalmazott, mivel jó szakítószilárdsággal és keménységgel, magas merevséggel, magas felületi ellenállással és jó szigetelő tulajdonságokkal rendelkezik. Az elmúlt évtizedben ezeknek a tulajdonságoknak a kiemelésére PMMA nanokompozitok készültek (Li et al., 2013). A polimer módosítók észszerü választások a kis molekulatömegü lágyítók helyett is, mivel elfogadható megoldást jelentenek a feldolgozás javítására és nem okoznak a migrációs problémákat a PVC szerkezetében. Azonban a PVC kompatibilitis keverékei más polimerekkel vagy kopolimerekkel való kezelésekor nem csak a reológiai tulajdonságok variációját eredményezi, hanem az olyan mechanikai tulajdonságaira is döntő hatással van, mint 
a nyújthatóság vagy szakadási szilárdság. Általában az összeférhetőség lesz az, amely megfogja határozni a polimer keverékek mechanikai és reológiai tulajdonságait (Hernández et al., 1999).

A polimer ömledék reológiai viselkedés tanulmányozásával a polimer minőségének ellenörzésére, szerszámtervezéshez, modellezéshez és a feldolgozási paraméterek beállítására is alkalmazhatjuk.

\section{Anyag és módszer}

Két eltérő PVC keverék reológiai tulajdonságait vizsgáltuk. Az egyik egy általános használatú kemény PVC hab, amely a feldolgozáshoz szükséges anyagok mellett, töltőanyagot is tartalmaz. A második keverékben az elözőhöz képest 100/20 tömegarányban PMMA polimer adalékot alkalmaztunk.

$\mathrm{Az}$ ömledék reológia megismerésével az anyag szerkezeti deformációját, degradációját határozhatjuk meg. Az ömledék folyási tulajdonságait a keverékhez alkalmazott polimer-polimer molekulatömege, annak láncszerkezete, feldolgozási hőmérséklete, degradációja fogja befolyásolni. Mivel kompozit keverékről van szó, ügyelni kell a megfelelő hőmérséklet beállításokra, a nagyobb mértékủ degradáció elkerülése érdekében.

\subsection{Reológiai tulajdonságok meghatározása}

$\mathrm{Az}$ ömledék reológiai tulajdonságok extruziométeres mérésből kapott adatokból határozhatók meg, úgymint viszkozitás, nyírósebesség és hőmérséklet. A vizsgálatot három hömérséklet program $\left(180,190,200^{\circ} \mathrm{C}\right)$ mellett, 20 és 100 fordulat/perc közötti csigafordulatszám változtatásával végeztük mind a két minta esetében. A fordulatszám emelésével a tömegáram növekedése, az anyagáramlása befolyásolható. Mérhető a $\mathrm{G}$ tömegáram [g/perc], az ömledék nyomása és hömérséklete az egyes zónákban.

\subsection{Viszkozitás értékeinek számításos meghatározása}

A nyírófeszültség és nyírósebesség felhasználásával a viszkozitás értékeit a kapilláris falra számítva határoztuk meg. Az alábbi összefüggések segítségével az extruziométeres vizsgálat eredményeiből a viszkozitás értékei kiszámíthatók. A méréshez tisztában kell lenni a résszerszám méreteivel, a mérési idővel, melyet ez esetben 1 percben határoztunk meg és a percenkénti tömeg adataival (Czvikovszky et al., 2007).

ahol:

$$
\tau_{a p}=\frac{H B}{2(H+B)} * \frac{p}{L}
$$

$\tau_{\text {ap }}$ - nyírófeszültség [MPa]

H- szerszámrés vastagság [mm]

B - szerszámrés szélessége [mm]

$\mathrm{p}$ - nyomás $[\mathrm{mm}]$

L - szerszámrés hossza $[\mathrm{mm}]$ 
ahol:

$$
\dot{\gamma}_{a p}=\frac{6 \dot{Q}}{B H^{2}}
$$

$\dot{\gamma}_{a p}$ - számított deformáció sebesség [1/s]

$\dot{Q}$ - térfogatáram $\left[\mathrm{mm}^{3} / \mathrm{s}\right]$

$\mathrm{H}-$ a szerszámrés vastagsága $[\mathrm{mm}]$

B - szerszámrés szélessége [mm]

$$
\dot{\gamma}=\frac{\dot{\gamma}_{a p}}{3} *\left(2+\frac{d \log \dot{\gamma}_{a p}}{d \log \tau}\right)
$$

ahol:

$\dot{\gamma}_{a p}$ - számított deformáció sebesség [1/s]

$\frac{d \log \dot{\gamma}_{a p}}{d \log \tau}-\log \dot{y}_{\text {ap }}=\mathrm{f}(\log \tau)$ görbe meredeksége

A nyírófeszültségi egyenlet (1) és a számított deformáció sebesség egyenlet (2) felhasználásával a Rabinowitsch-korrekció (3) meghatározható. A korrekciót a nyírósebesség kiszámításához alkalmazzák, mivel a newtoni viselkedéstől való eltérést határozza meg.

1. ábra: $\mathbf{1 8 0}^{\circ} \mathrm{C}$-on mért viszkozitási görbék

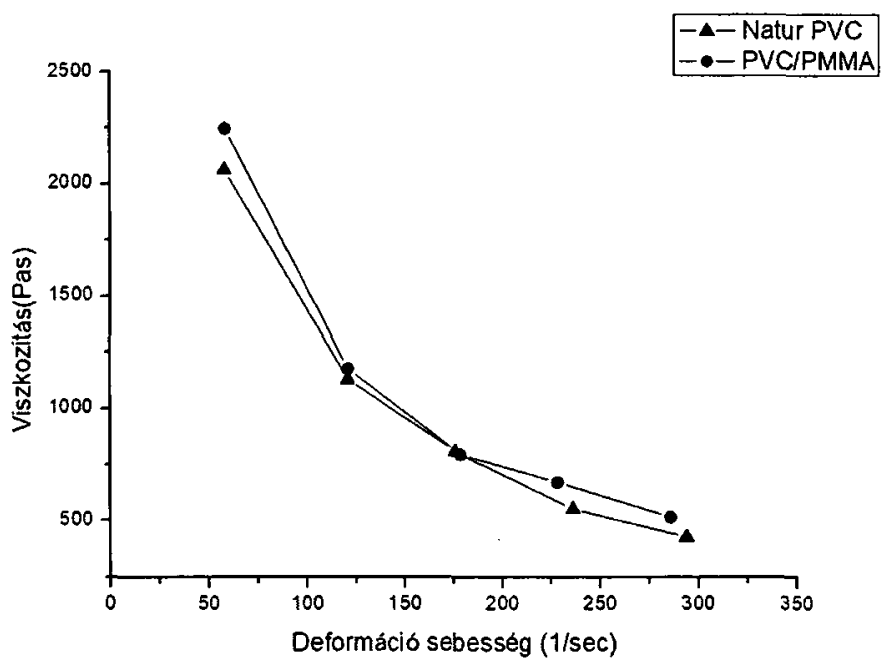

Forrás: A szerzö saját szerkesztése 
2. ábra: $190^{\circ} \mathrm{C}-o n$ mért viszkozitási görbék

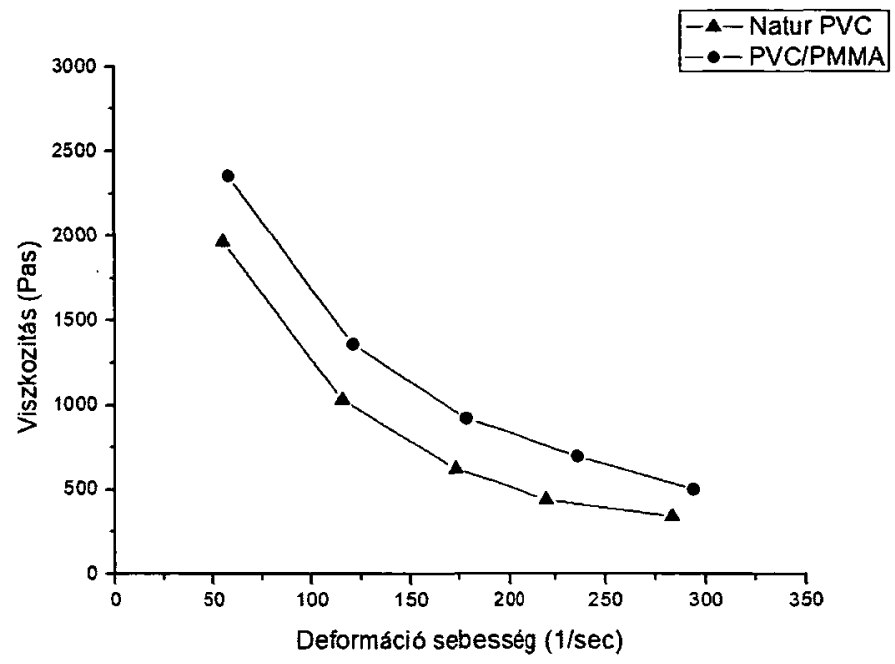

Forrás: A szerző saját szerkesztése

\section{3. ábra: $200^{\circ} \mathrm{C}$-on mért viszkozitási görbék}

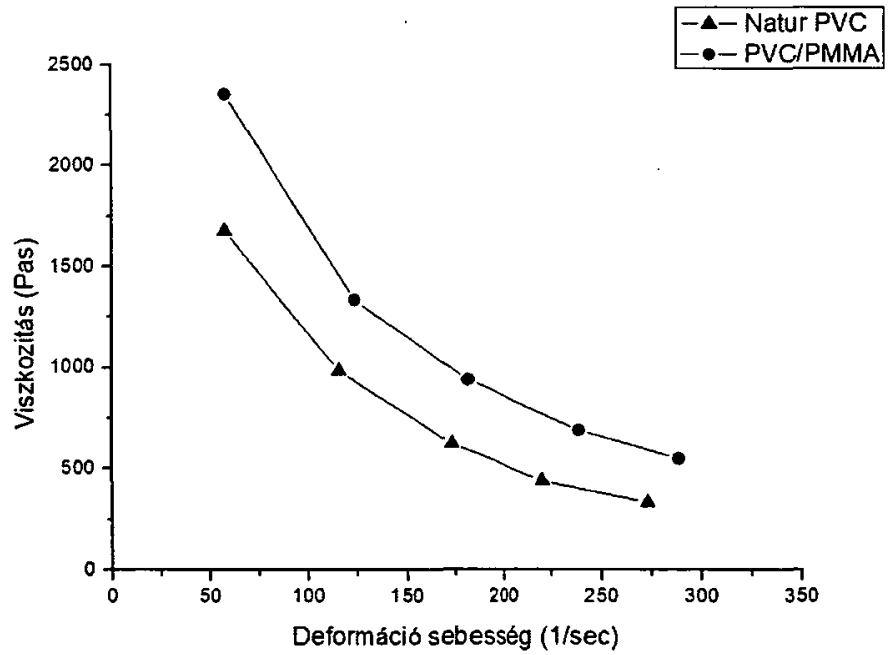

Forrás: A szerző saját szerkesztése

\section{Eredmények}

A reológia nagyban függ a keverékek molekulatömegétől, azonban a molekulatömeg (amely a tiszta polimerek viszkozitásához kapcsolódik) fontos szerepet játszik az összeférhetőség és a keverhetőség tekintetében is. A PVC/PMMA és kemény PVC hab keverék viszkozitás értékeinek tanulmányozásával és a szélsőséges hőmérsékletek alkalmazásával a viszkozitás deformáció függését határoztuk meg a vizsgált keverékek esetén. A PMMA polimer tartalmazó keverék reológiai 
viselkedése során minden hőmérsékleti tartományban magasabb viszkozitási értékek tapasztalhatók. Úgy tủnik, hogy a legmagasabb hőmérsékleti tartományban rendelkezik a PVC/PMMA keverék a legjobb reológiai tulajdonságokkal. Ez azt sugallja, hogy a keverék jó összeférhetőséggel rendelkezik. Másrészt erős a PVC és PMMA közötti kölcsönhatás, mivel a polimerek megfelelően elegyednek ömledék állapotban, emellett látható, hogy a PVC feldolgozás közbeni termikus tulajdonságait is javítja. Ez arra utal, hogy a PMMA könnyen elegyíthető a PVC-vel egy ipari extruderen is.

\section{Irodalomjegyzék}

Czvikovszky T., Nagy P., Gaál J. (2007): Polimertechnikai alapjai. <http://www.tankonyvtar.hu/hu/tartalom/tkt/polimertechnika-alapjai/ch05s02 html> (2017.10.21.)

Hernández, R., Pena, J. J., Irusta, L., Santamaría, A. (1999): The effect of a misciblie and an immiscible polymeric modifier on the mechanical and rheological propertied of PVC. European Polymer-Journal, 36 (5): 1011-1025.

Kumar, V., Weller, J. E., Ma, M., Montecillo R, Kwapisz, R. R. (1998); The effect of additives on

' Microcellular PVC foams: Part 2. Tensile Behavior. Cellular Polymers Journal, 17 (5): 350361.

Li, Y., Chen, Zh., Zeng, Ch. (2013): Poly(methyl Methacrylate) (PMMA) Nanocomposite Foams. In: Vikas M.: Polymer Nanocomposite Foams, 1-34

Panayiotou, C. (2013): Polymer - Polymer miscibility and partial solvation parameter. Polymer, 54 (6): 1621-1638.

Ray, S. S. (2013): Foam processsing, 351-352. (Elsevier) 